\title{
Little Creatures that Run the World: Bringing Ants to a Wider Audience
}

\section{Citation}

Barr, Dorothy. 2014. "Little Creatures That Run the World: Bringing Ants to a Wider Audience." Science \& Technology Libraries 33 (2) (April 3): 176-184.

\section{Published Version}

10.1080/0194262X.2014.912954

\section{Permanent link}

http://nrs.harvard.edu/urn-3:HUL.InstRepos:12274526

\section{Terms of Use}

This article was downloaded from Harvard University's DASH repository, and is made available under the terms and conditions applicable to Other Posted Material, as set forth at http:// nrs.harvard.edu/urn-3:HUL.InstRepos:dash.current.terms-of-use\#LAA

\section{Share Your Story}

The Harvard community has made this article openly available.

Please share how this access benefits you. Submit a story.

\section{Accessibility}




\title{
Little Creatures That Run the World: Bringing Ants to a Wider Audience \\ (Shortened version: Little Creatures That Run the World)
}

\begin{abstract}
Ants (Hymenoptera: Formicidae) are among the most ubiquitous and successful creatures on earth. They are the subject of research by ant biologists worldwide, and with over 8,800 identified species, access to quality information is important for those researchers. AntWiki (http://www.antwiki.org/) was created originally as an online listing of all ant taxonomists and their papers, and librarians have assisted the project by finding, scanning and uploading articles and contributing to a page on Human Culture and Ants.
\end{abstract}

\section{KEYWORDS}

Formicidae, ants, Hymenoptera, Antwiki, collaboration, wikis, taxonomies, systematics.

\section{INTRODUCTION}

Today we are experiencing an explosion of information sharing that is transforming research. The sciences have benefitted greatly, and a wide range of online vehicles have been created to facilitate this sharing. There are websites, blogs, webguides, wikis, etc. Some are officially sponsored by academic and research institutions; others are the work of interested amateurs; and there is everything in between. One collaboration of ant biologists, AntWiki (http://www.antwiki.org/), aims "to provide a wealth of information on the world's ants" (Antwiki, 2014) and gathers contributions from ant experts worldwide, making the information accessible to anyone with an Internet connection. Beginning in 2011 librarians, and for two 
years library school students, collaborated with the researchers to enhance Antwiki and worked together to further the world's knowledge of ants, the "little creatures that run the world" in E. O. Wilson's words (Upton 1995).

Figure 1. Antwiki Homepage.

\section{BACKGROUND}

It has always been important for researchers to share their work by whatever means available. Originally this was done informally, through writings and teachings. As far back as Egypt's Old Kingdom, around 3,000 years ago, the high priest Imhotep described surgical procedures on a papyrus known today as the Edwin Smith Papyrus (Finger 2000).The ancient Greek physician Hippocrates, known as the Father of Medicine, taught and wrote, though most of his written work has not survived (Hornblower, Spawforth, and Eidinow 2012). During the Renaissance in Europe, scholars regularly exchanged letters describing their work. Then with the founding of the Royal Society in 1660, physicians and scientists (then called "natural philosophers") got together to talk and to run experiments. In 1665 they began to publish the Philosophical Transactions of the Royal Society, and the modern scientific journal was born (Anonymous 2014).

Over time, the number of journals increased, their publication became more regular, and dissemination grew wider. Eventually authors were given a certain number of paper reprints that they could distribute to their colleagues to make their research more widely 
available. More recently, with the advent of e-journals, paper copies have fallen into disfavor and PDFs are the usual means of distribution of specific scholarly output.

In the field of natural history, taxonomic information has always been particularly important. In order to understand the behavior, evolution and phylogenetic relationships of species, it is necessary to first identify and classify them, and then publish and share the descriptions in order to make them available to others and to prevent duplication in identifying and naming species. Descriptions are collected in various ways, and the collections are usually local or regional in scope. Originally these bibliographies were printed, but today most taxonomic articles are also available electronically. The Internet has also opened up new avenues for creating online bibliographies that are dynamic and easy to keep updated.

\section{ANTS}

Ants (Hymenoptera: Formicidae) are among the most ubiquitous and successful creatures on earth. They first appear in the fossil record around 100 million years ago (Lapolla, Dlussky, and Perrichot 2013, 609-630). Today there are over 8,800 identified species worldwide, and there are undoubtedly many more that have not been described. Ants are found on every continent except Antarctica, and in a wide variety of habitats. They may be economically important in various ways. Sometimes their activities ruin crops or buildings, but they may also be helpful by turning over soil, recycling organic material, defending plants, spreading seeds, killing crop pests, and in other ways (Hölldobler and Wilson 1994).

Ants are "eusocial," along with only a handful of other taxa - some bees and wasps, all termites, a very few other insects, a couple of crustaceans, naked mole rats and humans 
(Wilson 2012). Eusociality is characterized by multiple generations living together and caring for young; maintenance and defense of the nest; and division of labor.

Ants are among the eusocial creatures that have castes; basically these are the reproductives (the queens and males) and the non-reproductives (the workers). Their haplodiploid system means that the workers are all sisters. Since the males - their fathers came from unfertilized eggs and contribute only one set of genes instead of the usual two, the workers share up to three-quarters of their genes with their sisters (depending on how many males mated with their mother the queen) while they would only share half their genes with any offspring they might produce. It therefore makes sense genetically for them to not only give up having offspring of their own but to work cooperatively for the good of the entire colony, even risking their lives.

Ants have highly efficient social structures. There is a queen (or sometimes queens) whose sole purpose in life is to mate, start the colony and lay eggs. Workers groom, feed and care for the queen and tend the young. Other workers forage for food, build and repair the nest, and defend the colony from attack from outside. In many ant species, workers take on different roles at different stages in their lives (Hölldobler and Wilson 1994).

With so many species around the world, keeping track of ant taxonomy - name changes, discoveries of new species and relationships between them - has never been easy. Originally, taxonomic records were occasionally gathered into print bibliographies, usually regional or local in scope; one example is Wheeler (1935). The first compendium of all taxonomic decisions for ants worldwide was prepared by Barry Bolton in 1995 (Bolton 2003). He followed that in 1996 with A Bibliography of Ant Systematics written with Philip Ward, 
Steve Shattuck and William Brown Jr. (Ward and others 1996), and In 2003 Synopsis and Classification of Formicidae (Bolton 2003). All these were printed.

\section{ANT TAXONOMY GOES ONLINE - THE GLOBAL ANT PROJECT, GAP}

In May 2008, a meeting of ant biologists from around the world was held at Harvard University to formally plan for an online listing of all ant taxonomic literature arranged by author. Bolton collaborated with Steve Shattuck of Australia's Commonwealth Scientific and Industrial Research Organisation (CSIRO) and Philip Ward of the University of California at Davis to create the Global Ant Project or GAP (http://gap.entclub.org/). They imported the Bolton bibliography and at a second meeting in November 2009 pulled together more ant biologists to work on the project. By 2011 almost 1,000 taxonomists were listed in GAP, with brief biographies, portraits when available, and lists of their publications with links to PDFs whenever possible. It was increasingly popular, receiving thousands of hits from all over the world and from almost every country (190 of 193 countries listed by the United Nations in 2011).

The author is a librarian at Harvard University's Ernst Mayr Library - Museum of Comparative Zoology (EML) and by 2011 was assisting the ant researchers in finding missing articles, scanning them as necessary and creating PDFs for upload to GAP. However, there were still many important but difficult to obtain articles missing, and progress was slow since the author has many other duties and could only sporadically devote time to the project.

Around this time, spring 2011, the Simmons College Graduate School of Library \& Information Science (GSLIS) launched an internship course, LIS 501 (http://www.simmons.edu/gslis/academics/courses/electives/index.php), and solicited partners around Greater Boston and surrounding areas to sponsor students. The interns were 
required to have completed all their requirements, so that they were nearing the ends of their programs, and to commit 120 hours of work. Recognizing that an intern would be perfect for the GAP project, the library applied for one, and in the summer term the first arrived at the EML. In succeeding semesters she was succeeded by four more.

We decided that the best approach was to go through the alphabet, filling in missing papers in order. Along with the author the first four interns worked systematically through the list, no small task in itself for several reasons. Many of the needed items were old, in obscure or defunct journals. Some were in languages other than English. To make matters worse the citations were often incomplete, abbreviated or simply incorrect, making it necessary to first disambiguate them. This might involve double-checking other sources that cited the references; for older items searching in the old Royal Society Catalogue of Scientific Papers; or looking through lists of abbreviations. The interns also created specific lists that they passed on to their successors.

Even with a correct citation, finding the actual item in the library could still be a challenge. The Library is 153 years old and although Library of Congress catalog numbers have been assigned to books since 1978, older items were cataloged using a homegrown classification system. For example, books about ants would have the basic call number MCZ HYM (Museum of Comparative Zoology - Hymenoptera), and within that section would be arranged by author's last names, and within each author's section by date in ascending order. Occasionally numbers had been appended to add to the confusion. Further, many items that were cataloged under the old system are not books but are reprints of journal articles, and since these are small they are often flimsily and sometimes randomly bound together, making 
finding an individual item difficult (and also making them very easy to misplace). So there were significant challenges for the interns, though happily they all rose to the occasion and even enjoyed the detective work. The Aha! feeling of satisfaction when one finally tracks down something after extended and complicated searching is familiar to all librarians.

As needed items were found, they were scanned and uploaded to GAP. The fourth intern, Marie Hviding, completed the list as best she could and then searched for missing portraits of the taxonomists with some success. The result of all the interns' work was that many difficult-to-get articles were made available to ant researchers worldwide, and GAP was greatly enhanced.

\section{GAP MOVES TO ANTWIKI}

In November 2010 Steve Shattuck demonstrated to the GAP ant biologists wiki software that he had been exploring as a possible replacement for GAP. Wiki technology would provide a more dynamic platform and be easier for researchers around the world to access and maintain. The biologists decided to move to the wiki format and at the same time to go beyond taxonomy and create species pages for all the ants of the world. Therefore, in 2012 Antwiki was formally launched and GAP was incorporated completely into it (http://www.antwiki.org). Antwiki proposes to provide "a wealth of information on the world's ants" (Antwiki 2014). The About page (http://www.antwiki.org/wiki/Antwiki:About) emphasizes the global scope of the project, the openness of the formats, the use of images and graphics (free to use but copyright remains with the owner), etc. (Anonymous).

Antwiki includes a number of sections, all easily accessed from the homepage. They are: 
- Identification and Species Accounts. There is a homepage for every known ant, with text, data, images, everything known about each animal. The pages can be browsed in various ways - by taxonomic rank; by country or region; by name; and more.

- Extinct Ants. This section is really about fossil ants. Some are fossilized in stone, though as with all insects these are often not well preserved despite the fact that insects were larger in the past than they are today. Others were trapped in plant resin that hardened; the resin is called amber if it is older than one million years, while younger resins are called copal. Ants so trapped are usually in better shape than ones fossilized in stone.

- Behavior. This in broken down into Ethograms; Foraging; Interspecific and Intraspecific Interactions; and Models of Ant Behavior, with subcategories under each.

- Distribution and Diversity. Ants are found in a wide variety of ecosystems, and this section allows the visitor to search by country or by taxonomic group, or to see maps of the distribution of all genera.

- Ant Societies. This section describes Life in an Ant Colony. It also includes Ants as Pests; Classification; Identification; a Glossary of Terms; Collecting Methods; and Specimen Preparation.

- Morphology, Anatomy and Terminology. This is subtitled Morphology and Terminology, and includes Morphological Terms; Surface Sculpturing (this describes, with photographs, the varying surfaces of various ants and parts of ants, with descriptive terminology defined); Morphological Measurements, defining the "core" measurements used in describing ants: Caste Terminology, defining the various casts of ants; and 
Terminology, with descriptions of the life history strategies such as subterranean, lignicolous, etc.

- Biochemistry, Genetics and Evolution. Included are Systematics (Phylogenetics); Genetics, with links to sequenced ant genomes where available, and also Karyotypes; Pheromones and Chemicals; and Pupal Development.

- Ecology. Much of this is still under construction, though the framework is set. It includes Ant Nests; Mimicry (nothing linked); and Morphological and Functional Diversity of Ant Mandibles. There are also sections on Species Interactions, Predators Specialized on Ants (no links) and Trophic Strategies (at this point the only link is to one species).

- Human Culture and Ants. The last intern, Katherine Bartolomea, worked extensively on this section. She searched various databases both in paper and online for anything ant related. This was work that neither the researchers (who simply want to study ants) or the author (who has a zoology background and is not particularly interested in popular culture) wanted to do. Using wiki markup language, Bartolomea contributed directly to content on Antwiki and created sections on Books \& Literature, with sortable tables for Fiction, Non-fiction and Children's Books; Movies \& Television; Music; Art; Photography; Games; Humor; and Food. One of the researchers, Dr. Gary Alpert, has added information about photographing ants and there are more topics listed but not yet populated.

- People and History of Myrmecology - this incorporates GAP, which remains as a standalone as well. However, this section of Antwiki is being constantly updated with new authors and articles while GAP is not. 
- A Table of Contents. This is still pretty bare.

- And finally, a "New to Antwiki? Start Here" page.

\section{Figure 2. Part of Human Culture and Ants Page.}

The wiki software means that Antwiki is dynamic and constantly growing; researchers around the world can upload to it or make edits as needed.

It's clear from even a quick perusal of Antwiki that much of the information is quite technical and mainly of interest to researchers. However, worldwide there are a lot of ant biologists and so far Antwiki has received over 3 million hits (Alpert 2014). For a biologist working in the field, being able to quickly access information about an ant in hand - to identify it and find out what is known about it - is very important. Researchers can look at photographs, read detailed descriptions, check relevant articles, and more. For a student wanting to know more about ants, or for a biology instructor looking for resources to help students identify and collect insects or to understand behavior, Antwiki has much to offer.

Even casual visitors can find interesting and useful information in Antwiki. There are instructions for collecting ants (http://www.antwiki.org/wiki/Collecting_Ants); a page on Ants as Pests (http://www.antwiki.org/wiki/Ants_as_Pests); sections on ways to identify ants (for example, http://www.antwiki.org/wiki/Ant_Identification); and of course the page on Human Culture and Ants (http://www.antwiki.org/wiki/Human_Culture_and_Ants) with its lists of books, films and more.

\section{CONCLUSION}


Antwiki is an excellent resource for ant biologists but also for entomologists or for those taking or teaching an entomology course. For librarians helping researchers find information or articles about ants, it is a rich resource. It can be helpful for ordinary people wondering how to deal with an ant infestation, or who just want to know more about ants. It also provides a model for making biological information widely available. Librarians can provide support and in so doing enhance the library's reputation and increase its visibility, showing that we can assist with research, save biologists time and effort, and help to provide resources for the advancement of scientific knowledge.

\section{BIBLIOGRAPHY}

"Antwiki." http://www.antwiki.org/Main_Page.

"Royal Society." accessed March/2014, 2014, http://en.wikipedia.org/wiki/Royal_society. Alpert, Gary. 2014.

Bolton, Barry. 2003. Synopsis and Classification of Formicidae. : Gainesville, FL: American Entomological Institute,.

Finger, Stanley. 2000. Minds Behind the Brain : A History of the Pioneers and their Discoveries. Oxford ;New York: Oxford University Press.

Hölldobler, Bert and Edward O. Wilson. 1994. Journey to the Ants : A Story of Scientific Exploration. Cambridge, Mass.: Belknap Press of Harvard University Press.

Hornblower, Simon, Antony Spawforth, and Esther Eidinow. 2012. The Oxford Classical Dictionary. Fourth edition / general editors, Simon Hornblower and Antony Spawforth ; assistant editor, Esther Eidinow. ed. Oxford: Oxford University Press. 
Lapolla, J. S., G. M. Dlussky, and V. Perrichot. 2013. "Ants and the Fossil Record." Annual Review of Entomology 58: 609-630.

Ants - Little Creatures Who Run the World. Directed by Nick Upton. Boston: WGBH, 1995.

Ward, Philip S., Barry Bolton, Steven O. Shattuck, and William L. Brown Jr. 1996. A Bibliography of Ant Systematics. Berkeley: University of California Press.

Wheeler, William Morton, 1865-1937. 1935. Check List of the Ants of Oceania, Vol. XI, no. 11. Honolulu, Hawaii,: The Museum.

Wilson, Edward O. 2012. The Social Conquest of Earth. 1st ed. New York: Liveright Pub. Corp. 